\title{
Reaching professional skills with the Final Master Thesis: Collaboration towards actual solutions
}

\author{
Irene Comeig Ramírez ${ }^{a}$, Alfredo Juan Grau Graub, Lucía Pinar Garcíac, Federico \\ Ramírez López ${ }^{d}$, Amalia Rodrigo González ${ }^{\mathrm{e}}$ \\ a, b, d, e Departamento de Finanzas Empresariales (Facultat d'Economía, Universitat de València \\ (SPAIN), $\quad \underline{\text { Irene.Comeig@uv.es, }} \quad \underline{\text { Alfredo.Grau@uv.es, }} \quad \underline{\text { Federico.Ramirez@uv.es, }}$
} Amalia.Rodrigo@uv.es

${ }^{\mathrm{c}}$ Departamento de Economía Aplicada (Facultat d'Economía, Universitat de València (SPAIN), Lucia.Pinar@uv.es.

\begin{abstract}
In order to motivate the student through a professional experience, and to improve the teaching-learning process by letting the student gain experience, we implement a collaborative learning-through-service methodology. This method increases the student involvement level and the deep understanding of the tools. As a matter of example, we present the implementation of this method in the Final Master Thesis (FMTh) of the Master on Corporate Finance at the University of Valencia (UV). In these FMTh, students have to valuate an actual innovation developed by UV researchers (on chemistry, in this case) with the goal of helping them to transfer (sell) this innovation to the industry. This collaborative learning-through-service methodology helps students put into practice the technics learned in the Master and give them a strong sense of the financial professional practice.
\end{abstract}

Keywords: Final Master Thesis, professional skills, learning through service, collaborative work methodology, financial valuation, actual solutions.

Acknowledgements: The authors acknowledge financial support from University of Valencia Vicerrectorado de Políticas de Formación y Calidad, UV-SFPIE_RMD17-589360. 


\section{Introduction}

At the end of the official master's degree, students must complete their corresponding Final Master Thesis (FMTh). The purpose of this FMTh is to complete the assimilation of the knowledge that has been acquired during the postgraduate studies, writing a theoreticalpractical essay on some topic related to the master.

In Spain, the RD 193/2007, October 29, regulates the official university education and establishes the obligation to complete the FMTh process to obtain the official master's degree. On the other hand, RD 1027/2011, July 15, focuses on the skills that graduates must acquire in a master. The competences related to the FMTh include, for example, knowing how to apply knowledge in new environments, evaluating and selecting the appropriate scientific theory and precise methodology to formulate judgments or know how to clearly transmit the results coming from scientific research.

Our contribution to the educational innovation lies in providing the student with a collaborative option to get involved in the professional domain while completing the FMTh. This intervention improves student's motivation; while this learning-throughservice process helps internalize professional techniques fostered through a collaborative tutoring model. In the example of application that we present, the FMTh of the Master on Corporate Finance at the University of Valencia (Spain), the student contacts a research group of the University of Valencia (through the webpage developed to advertise this teaching-learning project: RESEARCH + CASHLab, previous contacts, and/or brochures) and develops her Final Master Thesis (FMTh) by analyzing the financial viability of the transfer/sale to the industry of some research result of that group. Specifically, the question that is intended to answer is: What is the maximum price that a company should be willing to pay to acquire the exploitation rights of a specific research result (patent, license, process, etc.)?

This type of FMTh not only helps transfer research results from universities to industry, but also motivates students and allows them to experience inherent responsibilities of professionals in business finance. The financial valuation of the project translates products derived from the research into money, financial value and profitability, thus reducing the information asymmetry between researchers and potential buyers of these products, which facilitates the subsequent transfer of research results to the industrial environment. 


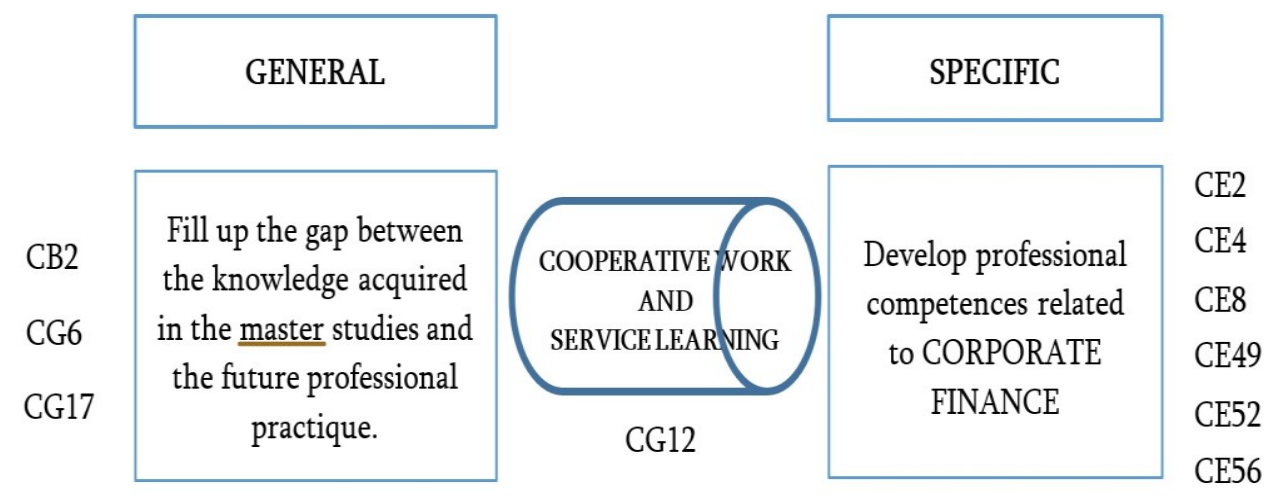

Fig. 1 Objectives and metodology

\section{Objectives}

The teaching-learning activity proposed in this paper has two main objectives, as Figure 1 shows, to be reached by students throughout their master thesis. On the one hand, students gain professional competences (on financial issues, in our example) by developing and applying the required skills. On the other hand, the gap between the academic knowledge and student's practice experience is reduced. To this twofold purpose, a mixed methodology combining Cooperative Work and Learning-throug-service methods help students acquire professional competences.

As Semeijn et al. (2005) claimed, the university system has the responsibility of providing students with adequate training, so that they may be able to efficiently do their work in the future. In the same line, Layer's (2004) and Heijke et al. (2003) expose the importance of the relationship between Higher Education and graduates' employability. Additionally, in order to evaluate competences acquisition or learning outcomes, competences should be defined in a precise way (need to be observable and measurable) allowing to clearly identify learning outcomes (Riesco, 2008),

Table 1 shows the description of competences to be acquired by students throughout the elaboration of a master thesis. 
Table 1. Professional competences

\begin{tabular}{|c|c|}
\hline Code & Description \\
\hline $\mathrm{CB} 2$ & $\begin{array}{l}\text { Students know how to apply their knowledge to their work or vocation in a } \\
\text { professional manner and possess the skills that are usually demonstrated through the } \\
\text { elaboration and defense of arguments and the resolution of problems within their } \\
\text { area of study }\end{array}$ \\
\hline CG6 & Ability to analyze and search information from different sources \\
\hline CG12 & Capacity for teamwork \\
\hline CG17 & Capacity for autonomous learning \\
\hline CE2 & $\begin{array}{l}\text { Students should be able to develop and interpret accounting information, both } \\
\text { financial, for external users, and internal, for management control and decision } \\
\text { making }\end{array}$ \\
\hline CE4 & $\begin{array}{l}\text { Students should be able to solve problems of financial valuation, both in financing } \\
\text { decisions, as business investment, in the national and international environment }\end{array}$ \\
\hline CE8 & $\begin{array}{l}\text { Students should know and analyze financial markets, as well as financial operations } \\
\text { attached to the business sector }\end{array}$ \\
\hline CE49 & Students should know the fundamentals of govern operations and financial markets \\
\hline CE52 & $\begin{array}{l}\text { Ability to measure and assess the risk of financial assets and their applications in real } \\
\text { investment projects }\end{array}$ \\
\hline CE56 & $\begin{array}{l}\text { Students should know the different financing instruments and be able to determine } \\
\text { the company's indebtedness policy }\end{array}$ \\
\hline
\end{tabular}

Font: Compiled by authors

The educational innovation proposal we present uses the methodology of Cooperative Work and, specifically, develops Service-Learning Pedagogy (SLP) with postgraduate students. Puig et al. (2009) define SLP in different ways by emphasizing two basic components: a) the effectiveness of learning and the curricular application of procedures and attitudes, b) the service given to the community, the transfer of research results to industry, in our example. Following Puig et al. (2006), SLP wants to respond to real needs of society by encouraging students' participation and cooperation with other institutions and entities beyond the university sphere. Hence, SLP also promotes values education through the very practice. Definitely, the integral knowledge, which is acquired with master studies, provides students with an updated tool kit that they can apply to give solutions to real problems or demands from the socio-business fabric.

Specifically, our contribution to educational innovation helps students to get engage in the professional reality during the completion of their FMTh. It is an attempt to reduce the gap between academic training and professional practice. This contribution:

1. Gives students a first opportunity to make contact with professional activities and practionners' skills. 
2. Improves the teaching-learning process by promoting that students internalize work techniques by they immersion in real cases with a real clients and consequences (it produces the Transfer of Research Results to the industry).

3. Encourages students' active and engaged participation by service-learning pedagogy. The relation is based on cooperative work between students, research groups and tutors.

4. It puts in contact the university study and the labor market, since students participate in a simulated marketplace where they hold interviews with companies interested in acquiring research results.

5. It has a positive impact on both students' training and the transfer of research results from the University of Valencia to industrial world.

6. In professional master studies, this kind of educational innovation focusing on FMThs accomplishes higher level of achievement than traditional approaches.

\section{Development of educational innovation}

\subsection{Cooperative Work and Service Learning Methodology}

In order to develop our educational innovation, we select Cooperative Work methodology. Because of its special features, it adequately fits pursued goals. As main advantage, this methodology comprises student-oriented teaching-learning methods, since the more students are involved in the very process, the more they are committed with and responsible for their own learning. As a consequence, students assimilate transforming and meaningful knowledge, which keeps available to be applied to different fields or situations in their future careers. According to Ariza (2000), this methodology promotes the acquisition of knowledge, skills or attitudes as a result of group work or, in other words, individual learning as a result of a group process.

In addition, some authors emphasize the fact of that students who are involved and engaged in a process to provide a solution to a real problem learn better and assimilate knowledge in a more permanent way than students following passive learning styles (Ramírez and GrauGrau, 2016; Comeig and Jaramillo-Gutiérrez, 2011; Hernández and Rodrigo, 2013; Rodrigo-González and Caballer-Tarazona, 2015)

In the implemented SLP experience, a three-side cooperation relationship is established: the student, the academic coordinator/mediator-tutor, and the research group. Therefore, the student receives academic and scientific support from both the coordinator/supervisor and the "client" group with which the student works in finding out a solution to a real problem. This triple interaction produces synergies enriching the quality of FMThs. 
The academic coordinator assumes a twofold role: as a responsible academician, she must promote that students make reflection and develop critical thinking. As a responsible group member she must coordinate the activities involved in the project to ensure that the cooperation process reaches a final result that is satisfactory for all interested parties.

Figure 2 shows the virtuous circle created in our example. The student gets in touch with a research group at the University of Valencia (thanks to the advertising made through triptychs and a website developed to publicize this teaching-learning project, RESEARCH+CASHLab, mainly) and she must perform a work (FMTh) on the financial viability of some research results to be transfered or sold to the industry.

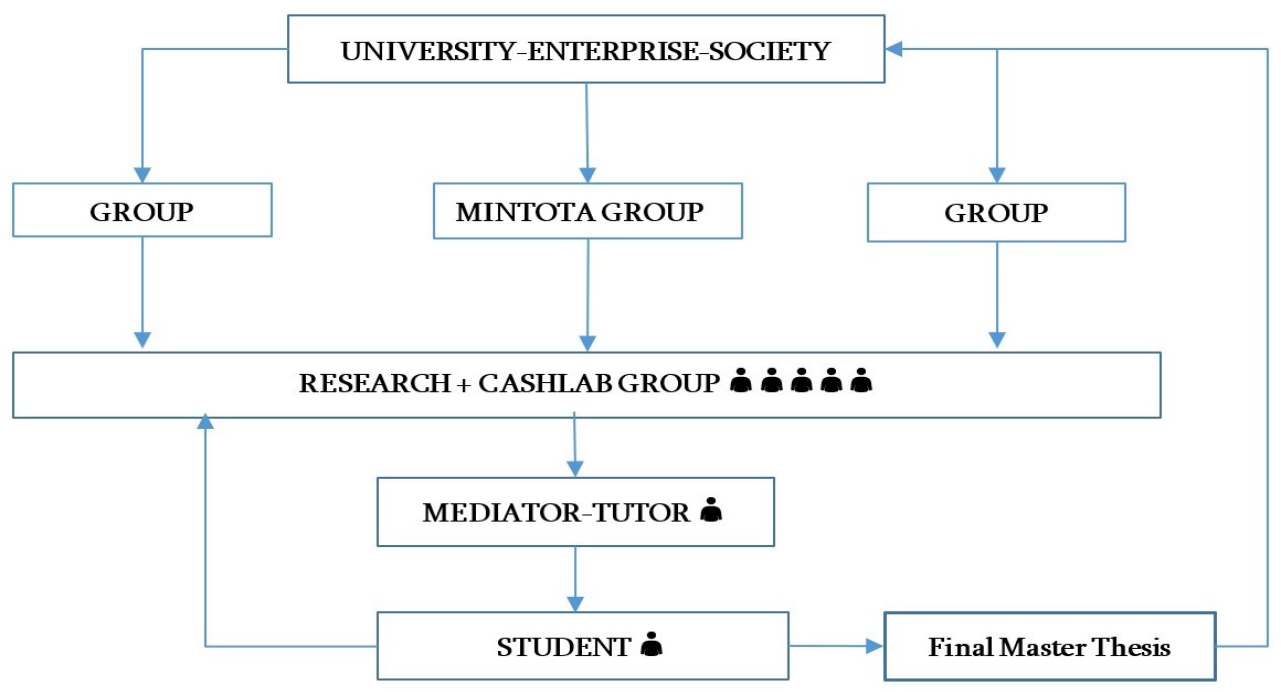

Fig. 2 Educative Innovation

This type of FMTh motivates students substantially and, in turn, transfers them the responsibility felt by practionners in charge of corporate finance. The financial valuation of the project reduces information asymmetries between researchers and potential clients/buyers of innovations (enterprises). As a consequence, it facilitates the subsequent transfer of research results to both enterprises and society.

\subsection{Example of application of the collaborative option of immersion in the professional reality during the realization of the FMTH}

Our educational innovation integrates Service Learning, which is applied by postgraduate students in Corporate Finance and Cooperative Work that allows different research and teaching groups to collaborate. In our example, MINTOTA group has a research product with a potential market share, RESEARCH + CASHLab group has the knowledge to give 
an economic-financial valuation to that product, and students in Corporate Finance are willing to apply the knowledge acquired in master studies to their FMTh.

As an example of our educational innovation, we present a FMTh devoted to assess a research product developed by MINTOTA group belonging to the Department of Analytical Chemistry (Faculty of Chemistry-UV). The innovation to be valued is an in situ colorimetric sensor that detects the amount of amines present in the air. This sensor may be very useful in the food industry. It shows the level of contaminants (amines) present in the food by using colors, which makes easy to identify how healthy the food is before being consumed.

RESEARCH + CASHLAB group is formed by researchers belonging to Corporate Finance Department (UV). This group represents a meeting point between researchers, investors and enterprises. For this reason, it is especially well positioned to offer academic and scientific support to those postgradute students in Corporate Finance who request to develop their master thesis under this service learning methodology. This group assesses scientific innovation such as new relevant findings, patents, licenses, etc., and so helps innovation eventually reaches the society and enterprise.

The educational innovation follows the five following phases:

\section{PHASE I. MEETING WITH MINTOTA RESEARCH GROUP}

In the first phase, the student and his supervisor meet with the members of the MINTOTA research group. They share relevant information on the innovation to be valued (passive atmospheric device), in special its superior characteristics over main competitors. The student is provided with all necessary data to make a financial valuation.

\section{PHASE II. DESIGN OF THE HYPOTHESES AND THE PREVISIONAL FINANCIAL STATEMENTS}

This is a key phase for the project to be good ended, that affects importantly the project valuation and profitability. The student along with his supervisor and RESEARCH + CASHLAB group stablish the set of hypotheses related to the following:

1. Assumptions about the estimation of direct labor costs: part-time staff, number of sensors to be manufactured per hour, etc.

2. Assumptions about the estimation of sales growth.

3. Assumptions about the estimation of fixed costs, advertising, depreciation derived from obtaining the license, etc.

4. Assumptions about the estimation of the Profit and Loss statement. 


\section{PHASE III. CALCULATION OF NET CASH FLOWS}

At this stage, the student must estimate the future net cash flows of the project, analyze some available means of financing, and determine the profitability of the project.

Net Cash Flow is a financial concept related to Earnings Before Interest and Taxes (EBIT), the investment in Fixed Asset and the investment in Net Operating Working Capital (NOWC). Any increase in net fixed assets represents a cash outflow, and any decrease represents a cash inflow. The book value of fixed assets decreases due to depreciation, and increases thanks to investments in Capex (capital expenditures).

\section{PHASE IV. STUDY AND ANALYSIS OF FINANCIAL INSTRUMENTS}

Next, the student applies several valuation methods to analyze the financial viability of the proposed project. Specifically, the methods are the following:

1. Net Present Value (NPV). It is a measure of net absolute profitability. This indicator will serve to identify if the value of the project is higher than its cost, taking into account the opportunity cost of capital.

2. Internal Rate of Return (IRR). It is a measure of gross return that allows us to decide whether or not to undertake a project.

3. Financial Break-Even Analysis. It determines the minimum number of sensors for the project to be profitable. Therefore, the project's NPV will be positive if sensor sales are higher than that minimum.

4. Sensitivity Analysis (SA). It allows us to identify dangerous scenarios that threat the project's viability, and keep such contingencies under monitoring.

5. Monte Carlo Method (MM). This method incorporates randomness in the variables defined by the user in order to study the proposed model. Specifically, for some variables, they were established minimum and maximum values, and 1,000 simulations of NPV were generated.

\section{PHASE V. ISSUANCE OF THE FINANCIAL EXECUTIVE REPORT}

Finally, the student issues two executive reports: a complete report, and a short version. These documents are delivered to MINTOTA group. After verifying the financial viability of exploitation of the passive devices is considered the exploitation of their license.

The activity ends when the student writes his master's thesis, which includes all the developments and findings aforementioned, according to the academic guide. 


\section{Results}

As a consequence of applying a collaborative methodology to provide real solutions (learning-through-service) in the development of FMThs, professional competences are acquired in a permanent way. The student internalizes the issues addressed (in our example: the financial assessment treated during the master). In addition, practical competences are acquired not only on financial valuation, but also on team work, transmission of idea, the student acquires professional experience (in our example on corporate finance), and the management of teamwork, but always under the supervision and collaboration of a teacher.

In our example, the main results of this innovation experience are enclosed into two spheres: the one academic and the other researcher. In first place, from the academic point of view: (i) the student applyes theoretical knowledge and takes contact with real companies by valuing real investment projects, which conduces to the elaboration of his thesis: "the evaluation of a license on a passive device for in situ detecting amines in gases". Additionally, (ii) most students who have developed this kind of tasks become employees in the same company.

On the other hand, in the field of research transfer: (i) MINTOTA group receives two executive reports, which give support to the trade of a license. In fact, other companies have already requested this economic-financial viability report. (ii) RESEARCH + CASHLAB group contributes to the transference of research results to the real business world. RESEARCH + CASHLAB group has recently organized the first Conference on Transmission of Research Results, led to postgraduate students, researchers, and companies. This space catches institutions interested in this kind of services, and students willing to develop professional activities.

\section{Conclusions}

The application of collaborative methodology to provide a solution to a real problem (learning-through-service) by a FMTh, allows the student to acquire long-lasting professional competences. The student internalizes the knowledge involved in the solution. In addition, other practical skills are acquired such as: teamwork, communication, collection of significant information, and management of time and responsibility. In short, the student acquires professional experience under the tutelage and with the collaboration of the professor.

Carrying out this innovation experience has allowed the students to make contact with the real business world and, therefore, develop a large part of the professional skills they need to adequately perform a job in the financial area. 
One of the main advantages of the interdepartmental collaboration (in our example: MINTOTA, RESEARCH + CASHLAB and Master on Corporate Finance) is that it allows developing high quality Master's thesis in Corporate Finance, in a real business context. As shown, synergies emerging in the entire process favor both academic and scientific results.

As a final conclusion, this kind of learning style makes possible a service through collaboration and produces excellent results; in our example, with the leadership of RESEARCH + CASHLAB group. In this way, it is possible to aproximate the different groups of interest involved: students, researchers and companies.

\section{References}

Ariza, A. (2000). Las Nuevas Tecnologías de la Información y la Comunicación y una Propuesta para el Trabajo Colaborativo. V Congreso Iberoamericano de Informática Educativa. Retrieved from: http://www.edudistan.com/Adolfo\%20Ariza.htm

Comeig, I., Jaramillo-Gutiérrez, A. (2011). Experimentos interactivos para la enseñanza de economía y finanzas: una aplicación a la docencia de estadística, en Experiencias de innovación docente en estadistica, Universidad de Valencia, Valencia. p. 191-199

Heijke, H., Meng, C., RiS, C. (2003). Fitting to the Job: The Role of Generic and Vocational Competencies in Adjustment and Performance. Labour Economics, 10, 215-229

Hernández, P., Rodrigo, A. (2013). ¿Cómo cooperan los estudiantes de primero de ADE? Trabajo en equipo: diseño basado en Economía Experimental. @ tic. revista d'innovació educativa, 10, 4454.

Layer, G. (2004). Widening Participation and Employability. York: Learning and Teaching Support Network.

Puig, J.M., Palos, J. (2006). Rasgos pedagógicos del aprendizaje-servicio. Cuadernos de Pedagogía, 357, 60-63.

Martín, M., Gijón, M, Bosch, C., Puig, J., Trilla, J., Palos, J., Batlle, R., Rubio, L., Climent, M.T., De la Cerda, M., Graell, M., Muñoz, A. (2009). Aprendizaje Servicio. Educación y compromiso cívico. Barcelona: Graó.

Ramírez, F., Grau-Grau A. J. (2016). La Innovación Educativa y la Economía Experimental: Un experimento sobre el contagio del pánico bancario. En Innovación Universitaria: Digitalización 2.0 y Excelencia en Contenidos. Mc Grau Hill/ Interamericana. Madrid. 665-676.

Real Decreto 1393/2007, de 29 de octubre, por el que se establece la ordenación de las enseñanzas universitarias oficiales (publicado en BOE núm. 260, de 30 de octubre de 2007). Retrieved from: https://www.boe.es/diario_boe/txt.php?id=BOE-A-2007-20202

Real Decreto 1027/2011, de 15 de julio, por el que se establece el Marco Español de Cualificaciones para la Educación Superior (publicado en BOE núm. 185, de 3 de agosto de 2011). Retrieved from: https://www.boe.es/buscar/doc.php?id=BOE-A-2011-13317 
Riesco, M. (2008). El enfoque por competencias en el EEES y sus implicaciones en la enseñanza y el aprendizaje. Tendencias pedagógicas, 13, 79-106.

Rodrigo-González, A., Caballer-Tarazona, M. (2015). A model to assess students' social responsibility behavior within a classroom experiment.International Review of Economics Education, 18, 62-82.

Semeijn, J.H., Velden, R.K.., Heijke, J.A.., Vleuten, C.P., Boshuizen, H.C. (2005). Competence Indicators in Academic Education and Early Labour Market Success of Graduates in Health Sciences. Maastricht: Research Centre for Education and the Labour Market. 